Proc. Estonian Acad. Sci. Biol. Ecol., 2001, 50, 1, 14-21

\title{
DISTRIBUTION OF MYSIDS ON BANK SLOPES IN THE GULF OF RIGA
}

\author{
Ilmar KOTTA and Jonne KOTTA
}

Estonian Marine Institute, Marja 4d, 10617 Tallinn, Estonia: jonne@ sea.ee

Received 13 October 2000

\begin{abstract}
The abundance and biomass distribution of mysids were estimated on two bank slopes of the Gulf of Riga in 1977-80. The distribution of mysids was aggregated and related to the temperature conditions. Higher densities of mysids coincided with the areas where the thermocline boundaries touched the sea floor. In these biotopes with strong temperature gradients mysids were often observed outside of their natural temperature preferences. Mysis relicta was recorded above the thermocline at $10^{\circ} \mathrm{C}$ and Neomysis integer below the thermocline at $2^{\circ} \mathrm{C}$.
\end{abstract}

Key words: Mysis, Neomysis, frontal zone, Baltic.

\section{INTRODUCTION}

Coastal slopes are often characterized by higher biological productivity as compared to adjacent deep or shallow water biotopes and therefore these areas are of great interest among marine biologists (Barnes \& Hughes, 1988). Elevated productivity is due to the upwelling process, which supplies surface layers with nutrient-rich deep water. Consequently, the water masses of different origin meet and an active mixing takes place. Whenever these processes are relatively frequent very high pelagic and benthic productions are observed in the area.

Earlier studies have demonstrated high production of phytoplankton (Kahru et al., 1984; Kononen et al., 1996), and zooplankton and fish (Oyaveer \& Kalejs, 1974; Ojaveer, 1997) in the frontal zones of the Baltic Sea. Mysids, being an important component in the food chain, however, have been neglected in terms of their quantitative distribution in the hydrodynamically active areas. There exists some evidence that higher densities of mysids often occur on steep slopes where strong gradients in temperature are observed (Kotta \& Kotta, 1999).

The aim of this study was to quantify the distribution of mysids in relation to temperature gradients on two bank slopes in the Gulf of Riga. Owing to intensive 
water currents both areas are subjected to frequent upwelling processes. The two selected sites differ in the steepness of their bottom morphology. Our main hypothesis is that temperature gradients rather than temperature per se influence the spatial pattern of mysid distribution. Higher densities are expected in the areas where the temperature gradients are stronger.

\section{MATERIAL AND METHODS}

Sampling was performed on two bank slopes adjacent to Kihnu Island during June 1977-80 (Fig. 1). June was selected for sampling as the thermocline is best developed on the slopes during that time of the year. A transect was located on each slope so that it covered both the shallower and deeper parts of the slope.

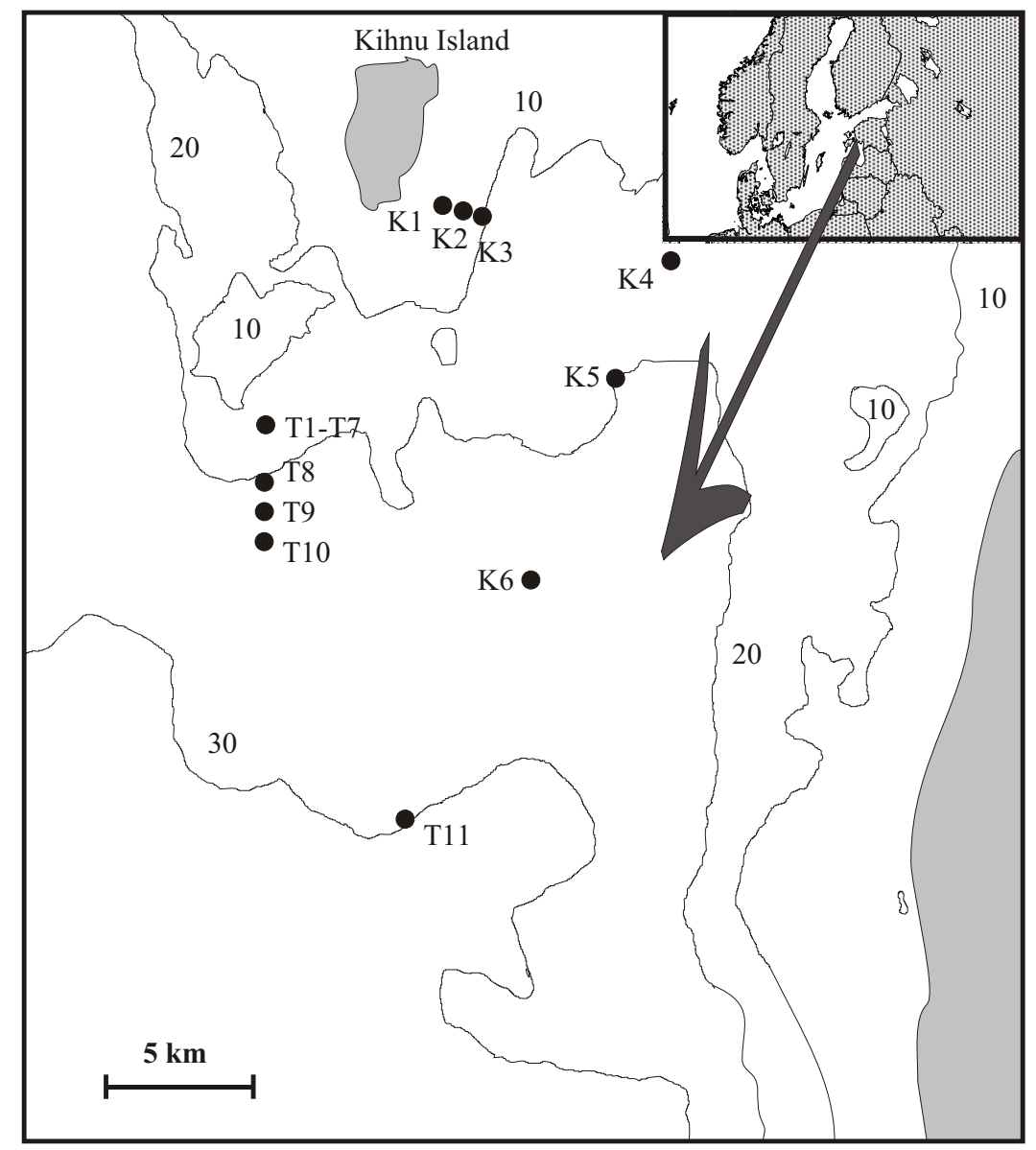

Fig. 1. Study area with depth isolines shown. T1-T11 and K1-K6 represent the stations on the Tibriku and Kihnu transects, respectively. 
The distance between stations ranged between 0.1 and 1.5 nautical miles. The reference stations (T11, K6), used to quantify the density of mysids away from coastal slopes, were situated 5-6 miles from the deepest stations of the transect towards the deeper part of the sea.

In each station the water temperature was measured from sea floor to surface with a depth interval of $2 \mathrm{~m}$. Mysid density was estimated by means of day-time horizontal hauls undertaken with a modified Rass dredge (Rass, 1933; Kotta \& Kotta, 1999). The mesh size of the net was $0.4 \mathrm{~mm}$. For more detailed procedure of sampling see Kotta \& Kotta (1999).

\section{RESULTS}

We followed the sharp thermocline lying between 15 and $20 \mathrm{~m}$ on the Kihnu transect and between 20 and $25 \mathrm{~m}$ on the Tibriku transect during most of the study periods. In the areas where the thermocline boundaries coincided with the sea floor an about 2-3 $\mathrm{m}$ rise of the thermocline was observed.

The distribution of mysids on the studied bank slopes was aggregated and significantly related to temperature conditions. During the whole study period the abundance and biomass values of mysids were relatively low both in the shallowest and deepest parts of the bank slopes as well as in the reference areas. Significantly higher abundance and biomass values were observed in the areas where the thermocline touched the bottom. The densities exceeded manifold these in the adjacent sea. The bottom water temperatures varied between 1.3 and $17.3^{\circ} \mathrm{C}$ on the studied bank slopes and were between 1.5 and $4.0^{\circ} \mathrm{C}$ in the areas where mysids had higher densities.

The dominant mysid species was Mysis mixta Lilljeborg. We also found Neomysis integer (Leach) and M. relicta Lovén. N. integer was found in the shallower areas but Mysis spp. occurred mainly in the deepest parts of the study area.

M. mixta dominated in most of the studied depth range on the Tibriku transect except in its deepest part where the proportion of M. relicta was highest (Fig. 2). Besides the deepest parts of the transect, $M$. relicta occurred up to $20 \mathrm{~m}$, which is the lower limit of the depth distribution of the shallow water mysid $N$. integer. $M$. relicta was always confined to areas where the bottom water temperature did not exceed $3{ }^{\circ} \mathrm{C}$. $N$. integer was found both below and above the thermocline.

The mysid species that contributed most to the peak density on the Kihnu transect varied between different years (Fig. 3). M. mixta usually prevailed in the frontal areas, $N$. integer occurred above the thermocline, and M. relicta below the thermocline. However, the highest densities of $N$. integer were often observed in the vicinity of frontal areas. In 1978 M. relicta was also found in high numbers in the shallower part of the transect at a depth of $10 \mathrm{~m}$. The bottom water temperature of the area exceeded $10{ }^{\circ} \mathrm{C}$, which is hardly considered a "norm" of this glacial relict. The main difference in the hydrological conditions between 


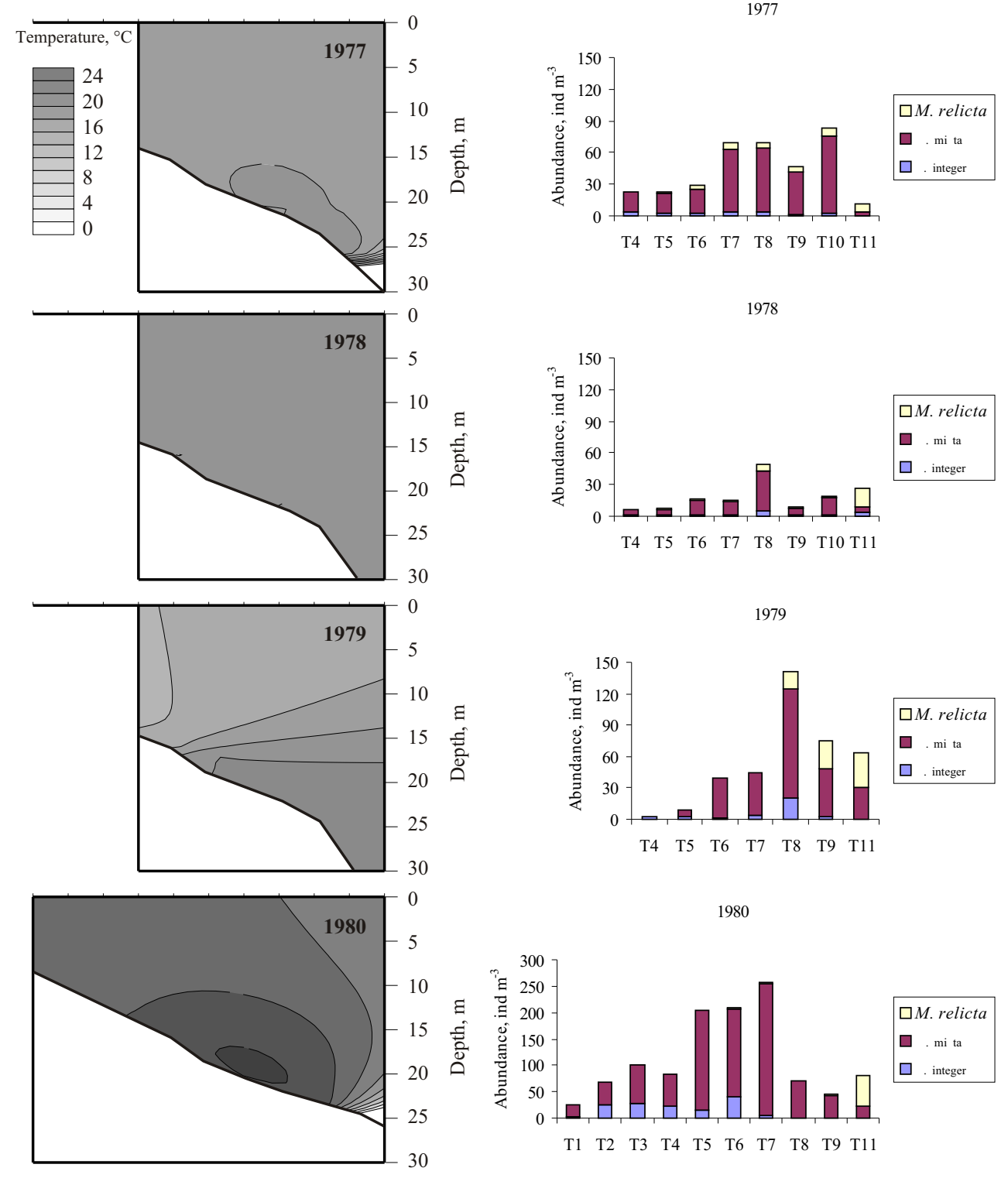

Fig. 2. Temperature profiles (left) and abundance distribution of mysids (right) on the bank slope of the Tibriku transect in 1977-80. 


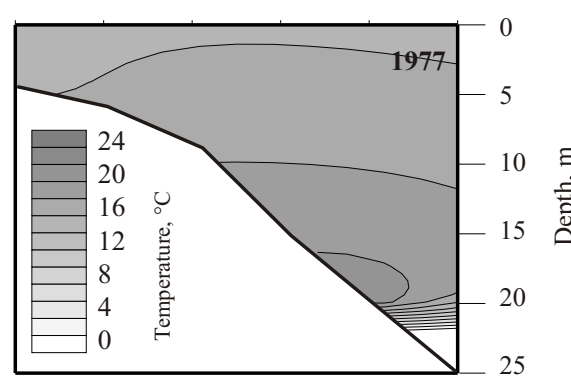

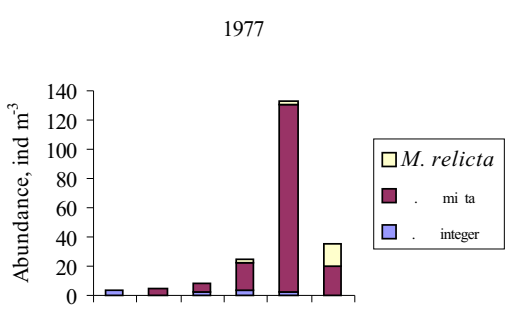

$\begin{array}{lllllllllll}\mathrm{K} 1 & \mathrm{~K} 2 & \mathrm{~K} 3 & \mathrm{~K} 4 & \mathrm{~K} 5 & \mathrm{~K} 6\end{array}$

1978

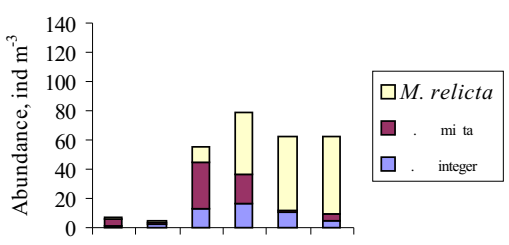

K1 $\quad$ K2 $\quad$ K3 $\quad$ K4 $\quad$ K5 $\quad$ K6

1979

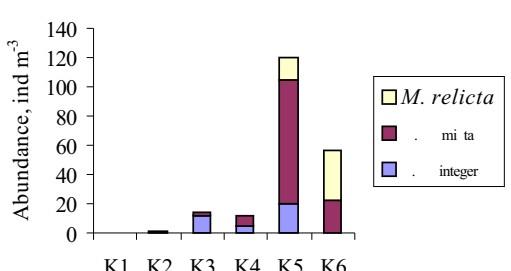

980

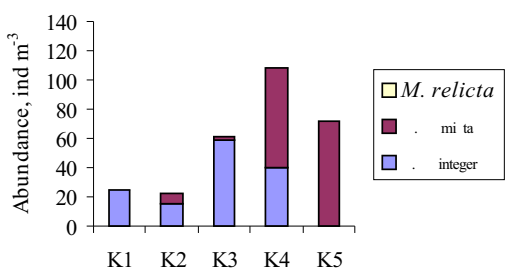

Fig. 3. Temperature profiles (left) and abundance distribution of mysids (right) on the bank slope of the Kihnu transect in 1977-80. 
1977 and 1978 was the substantial increase in the bottom water salinity from 6 to 7 PSU. The increasing salinity, in turn, might have triggered the changes in the dominance structure of mysids in the study area.

\section{DISCUSSION}

This study demonstrated that different mysid species aggregate in the areas where strong gradients of temperature are observed. This is in accordance with our previous observations in the Gulf of Riga (Kotta \& Kotta, 1999), where we showed very high densities of mysids in straits, river estuaries, and bank slopes, i.e. in areas that are subjected to strong spatial and temporal variation in water temperature. The settling of the mysids in the vicinity of the temperature discontinuity layer indicates that mysid species perform horizontal migrations following the displacement of the thermocline. The migration of mysids is induced by the temperature gradient rather than temperature limits. Our reasoning is as follows. Firstly, the maximum densities of mysids were not observed at constant temperatures. Secondly, the maxima were always found in the areas where the thermocline boundaries coincided with the sea floor. In the deeper areas at similar temperatures the density of mysids was substantially lower than in the frontal areas.

Similar migrations following the changes in water temperature have been observed for other mysid species (Hakala, 1978; Morgan et al., 1978; Bourdillon \& Castelbon, 1983). The phenomenon is particularly important in the hydrodynamically active areas as seen in our study area where the populations of mysids are permanently submitted to spatial and temporal temperature gradients.

However, the changes in water temperature alone cannot explain the distribution pattern of mysids in the study area as specimens $M$. relicta were also reported above the thermocline and $N$. integer below the thermocline, i.e. outside of their normal habitat (Yarvekyulg, 1979; Kotta, 1984). Hence, other factors such as the distribution of phytoplankton and zooplankton may lie behind this relationship (Kotta, 1984). Earlier studies have reported higher phytoplankton density in the areas where the thickness of the warmed up layer of surface water is reduced (Kahru et al., 1984). In the case of a similar prey density mysids have an advantage of staying in the colder parts of the slope as lower temperatures increase the clearance rates of mysids owing to lower escape responses of zooplankton at low temperatures (Cooper \& Goldman, 1982).

Mysids are opportunistic omnivores being capable of utilizing large phytoplankton and zooplankton species but also bottom detritus and organic material in suspension (Mauchline, 1971; Grossnickle, 1982; Lasenby et al., 1986; Rudstam \& Hansson, 1990). In the Baltic Sea their diet is mainly dominated by zooplankton (Kinne, 1955; Arndt \& Jansen, 1986; Rudstam \& Hansson, 1990). As seen in this study the distribution areas of different mysid species with 
different habitat preference overlap on the bank slopes. In such biotopes mysids may be observed in very high numbers. Hence, higher concentration of mysids is likely to modify the species composition and density of phytoplankton and zooplankton. As mysids are the major forage species of herring and smelt (Aneer, 1975; Ojaveer, 1997) they are also expected to change the relative abundance of different fish species present.

Such aggregations of mysids are likely to develop in the other bank slopes of the Gulf of Riga and elsewhere where the formation of a thermocline is more likely. In order to estimate the relative contribution of mysids to the large-scale matter and energy flows one has particularly to take into account the bank slopes as their role in the ecosystem functioning can be hardly overestimated.

\section{ACKNOWLEDGEMENTS}

The study was carried out within the framework of Estonian Governmental Programmes Nos. 0200792s98 and 0200797s98.

\section{REFERENCES}

Aneer, G. 1975. Composition of food of the Baltic herring (Clupea harengus $v$ membras L.), fourhorn sculpin (Myoxocephalus quadricornis L.) and eel-pout (Zoarces viviparus L.) from deep soft bottom trawling in the Askö-Landsort area during two consecutive years. Merentutkimuslait. Julk., 239, 146-154.

Arndt, E. A. \& Jansen, W. 1986. Neomysis integer (Leach) in the chain of Boddens South of Darss/Zingst (Western Baltic) - ecophysiology and population dynamics. Ophelia, Suppl., 4, 1-15.

Barnes, R. S. K. \& Hughes, R. N. 1988. An Introduction to Marine Ecology. Blackwell Scientific Publ., Oxford.

Bourdillon, A. \& Castelbon, C. 1983. Influence des variations de température sur la géotaxie de deux espèces de mysidacés. J. Exp. Mar. Biol. Ecol., 71, 105-117.

Cooper, S. D. \& Goldman, C. R. 1982. Environmental factors affecting predation rates of Mysis relicta. Can. J. Fish. Aquat. Sci., 38, 203-208.

Grossnickle, N. E. 1982. Feeding habits of Mysis relicta - an overview. Hydrobiologia, 93, 101-107.

Hakala, I. 1978. Distribution, population dynamics and production of Mysis relicta (Lovén) in southern Finland. Ann. Zool. Fenn., 15, 243-258.

Kahru, M., Elken, J., Kotta, I., Simm, M. \& Vilbaste, K. 1984. Plankton distributions and processes across a front in the open Baltic Sea. Mar. Ecol. Prog. Ser., 20, 101-111.

Kinne, O. 1955. Neomysis vulgaris Thompson, eine autökologisch-biologische Studie. Biol. Zentralbl., 74, 160-202.

Kononen, K., Kuparinen, J., Mäkelä, K., Laanemets, J., Pavelson, J. \& Nõmmann, S. 1996. Initiation of cyanobacterial blooms in a frontal region at the entrance to the Gulf of Finland, Baltic Sea. Limnol. Oceanogr., 41, 98-112.

Kotta, I. 1984. Abundance, biomass and seasonal migration of Mysidacea in the Gulf of Riga. In Hydrobiological Regime of the Baltic Sea, pp. 92-101. Tallinn (in Russian). 
Kotta, I. \& Kotta, J. 1999. Distribution and migration of mysids in the Gulf of Riga (northern Baltic). Proc. Estonian Acad. Sci. Biol. Ecol., 48, 284-295.

Lasenby, D. C., Northcote, T. G. \& Fürst, M. 1986. Theory, practice and effects of Mysis relicta introductions to North American and Scandinavian lakes. Can. J. Fish. Aquat. Sci., 43, 1277-1284.

Mauchline, J. 1971. The biology of Neomysis integer (Crustacea, Mysidacea). J. Mar. Biol. Ass. U.K., 51, 347-354.

Morgan, M. D., Threlkeld, S. T. \& Goldman, C. R. 1978. Impact of the introduction of konanee (Oncorhynchus nerka) and oppossum shrimp (Mysis relicta) on a subalpine lake. J. Fish. Res. Bd. Can., 35, 1572-1579.

Ojaveer, H. 1997. Composition and dynamics of fish stocks in the Gulf of Riga ecosystem. Disser. Biol. Univ. Tartuensis, 31.

Oyaveer, E. A. \& Kalejs, M. V. 1974. On some oceanographic factors determining the abundance and distribution of pelagic fish in the Baltic Sea. Okeanologiya, 14, 544-554 (in Russian).

Rass, T. 1933. Guide for the Quantitative Sampling of Roe and Marine Larvae. GOIN, Moskva (in Russian).

Rudstam, L. G. \& Hansson, S. 1990. On the ecology of Mysis mixta (Crustacea, Mysidacea) in a coastal area of the northern Baltic proper. Ann. Zool. Fenn., 27, 259-263.

Yarvekyulg, A. 1979. The Benthic Fauna in the Eastern Part of the Baltic Sea. Valgus, Tallinn (in Russian).

\section{MÜSIIDIDE LEVIK LIIVI LAHE MADALIKUNÕLVADEL}

\section{Ilmar KOTTA ja Jonne KOTTA}

On vaadeldud müsiidiliikide arvukust ja biomassi kahel Liivi lahe madalikunõlval aastail 1977-1980. Müsiidid olid kobardunud ning seotud temperatuuritingimustega madalikunõlvadel. Müsiidide arvukus oli kõrgeim aladel, kus termokliin puudutas merepõhja. Nendes piirkondades täheldati müsiidide rändeid väljapoole oma temperatuurioptimumi. Mysis relicta isendeid leiti ülalpool termokliini $10^{\circ} \mathrm{C}$ juures ning Neomysis integer'i isendeid allpool termokliini $2^{\circ} \mathrm{C}$ juures. 